\title{
Antioxidant property and polyphenols evaluation of aqueous root extract of Decalepis hamiltonii Wight \& Arn.
}

\author{
*Ponnusamy Samydurai, Vellaichamy Thangapandian \\ PG E Research Department of Botany, Kongunadu Arts and Science College (Autonomous), Coimbatore - 641 029, \\ Tamil Nadu, India
}

\begin{abstract}
Antioxidant activity, total phenol and flavonoids estimation of the aqueous extract of the tuberous root of Decalepis hamiltonii was evaluated by free radical scavenging activity using 2,2-diphenylpicryl-1-picrylhydrazyl (DPPH), metal chelating activity, superoxide scavenging activity, ferric reducing antioxidant power assay (FRAP) and 2,2'azinobis (3ethylbenzothiozoline-6-sulfonic acid) disodium salt (ABTS $\left.{ }^{\bullet}\right)$ assay. The content of polyphenols in the extract was determined by spectrophotometrically, calculated as gallic acid and catechin equivalent. The present investigation revealed that this plant has rich source of antioxidant properties. Naturally, tuber of this plant has been traditionally used as food by the tribal communities. Hence it is inferred that this plant is not only being as food and it can also be a good source of health tonic.
\end{abstract}

Key Words: Decalepis hamiltonii, free radical scavenging activity, gallic acid, catechin.

\section{INTRODUCTION}

Decalepis hamiltonii Wight \& Arn (Asclepiadaceae) is a monogeneric climbing shrub native of Deccan peninsula and forest areas of Western Ghats of India. The rhizome is largely used for pickling along with curd or limejuice (Anon, 1952). People procure and habitually carry the roots with them and chew the same whenever the digestion may seek relief. Besides treating indigestion the roots have been used locally to stimulate the appetite and to relieve flatulence and act as a general tonic (Vedavathy, 2004). In Decalepis hamiltonii the tuberous root extract contain the flavor compound 2-Hydroxy 4methoxybenzaldehyde as a major compound (97\%) which is extractable by steam distillation method followed by using dichloro methane (Giridhar et al., 2004). The flavonoids are a category of natural substances belonging to the family of polyphenols. The main function seems to be the coloration of plants (just like chlorophyll and carotenoids). The presence

\footnotetext{
*Corresponding Author:

Ponnusamy Samydurai, Research Fellow

PG \& Research Department of Botany

Kongunadu Arts and Science College (Autonomous)

Coimbatore - 641 029, Tamil Nadu, India

E-mail: samydurai.bio@gmail.com

Contact No.: +919442174805
}

of flavonoids in the plant is sometimes concealed under their leuco shape, which explains their commercial interest in the food industry (Fiorucci, 2006).

The natural antioxidants may have free-radical scavengers, reducing agents, potential complexes of peroxidant metals, quenchers of singlet oxygen (Ebadi, 2002). The antioxidants can interfere with the oxidation process by reacting with free radicals (Gupta et al., 2004). Recently interest has been increased considerably in finding natural occurring antioxidants for use in foods or medicinal materials to replace synthetic antioxidants which are being restricted due to their side effects such as carcinogenicity (Kumaran and Karunakaran, 2007).

\section{MATERIALS AND METHODS}

\section{Chemicals}

All the chemicals and solvents were of analytical grade and were obtained from Himedia chemicals, Mumbai, India. 2, 2 - azinobis 3-ethylbenzothiozolin-6-sulphonate (ABTS) was obtained from Sigma chemicals, USA. The other chemicals used were Gallic acid, $\alpha$-Tocoperol, Rutin, 2,2diphenylpicryl-1-picrylhydrazyl (DPPH), Tert- 
butylated hydroxytoluene (BHT), Ethylene diamine tetra acetic acid (EDTA), Trolox, Potassium persulphate.

\section{Plant material}

The tubers of $D$. hamiltonii were collected from tribal inhabitat from above 700 to $1000 \mathrm{~m}$ of Kolli Hills, Namaakkal, Tamilnadu. The freshly harvested tubers were methodically washed and air dried in our laboratory. They were authenticated at the Botanical Survey of India (Southern part of Coimbatore). The voucher specimen was deposited at the Institute's herbaria.

\section{Preparation of aqueous extract}

$25 \mathrm{~g}$ of root powder was dissolved in $100 \mathrm{ml}$ of boiled distilled water in a conical flask kept on rotary shaker for 12 hours under 80rpm, residue was filtered using No. 1 Whatman filter paper. The residues were then collected and dried to dryness first on a water bath and then in an oven. After drying, the residue was weighed and scraped out and different aliquots were dissolved in $5 \mathrm{ml}$ of sterile water and stored at $4^{\circ} \mathrm{C}$ for further analysis.

\section{Total Polyphenol content}

The total phenol content was determined by the method described by Siddhuraju and Becker (2003). Aliquots $(250 \mu \mathrm{l})$ of each extracts were taken in test tubes and made up to the volume of $1 \mathrm{ml}$ with distilled water. Then $0.5 \mathrm{ml}$ of Folin-Ciocalteu phenol reagent (1:1 with water) and $2.5 \mathrm{ml}$ of sodium carbonate solution (20\%) were added sequentially in each tube. Rapidly after vortexing the reaction mixture, the test tubes were placed in dark for 40 minutes and the absorbance was recorded at $725 \mathrm{~nm}$ against reagent blank. All determinations were carried out in triplicate. The total phenolic compound in the extract in gallic acid equivalent (GAE) was calculated.

Flavonoid contents were determined according to the method of Zhishen et al. (1999). An aliquot (250 $\mu \mathrm{l})$ of each extract or standard solution was mixed with $1.25 \mathrm{ml}$ of DD $\mathrm{H}_{2} \mathrm{O}$ and $75 \mu \mathrm{l}$ of $5 \% \mathrm{NaNO}_{2}$ solution. After $6 \mathrm{~min}, 150 \mu \mathrm{l}$ of $10 \% \mathrm{AlCl}_{3} \cdot \mathrm{H}_{2} \mathrm{O}$ solution was added. After $5 \mathrm{~min}, 0.5 \mathrm{ml}$ of $1 \mathrm{M} \mathrm{NaOH}$ solution was added and then the total volume was made up to $2.5 \mathrm{ml}$ with double distilled water. Following thorough mixing of the solution, the absorbance against blank was determined at $510 \mathrm{~nm}$. The results were expressed in $\mathrm{mg}$ catechin equivalent (CE).

\section{DPPH free radical scavenging activity}

DPPH scavenging activity of this plant tuber extract was measured according to the method of Blios (1958). IC 50 values of the extracts and concentration of the extracts necessary to decrease the initial concentration of DPPH by $50 \%$ were calculated.

\section{Metal chelating activity}

The chelating activity of ferrous ions by aqueous extract was estimated by the method (Dinis et al., 1994). Briefly the extract sample $(250 \mu \mathrm{l})$ was added to a solution of $2 \mathrm{mmol} / \mathrm{L}$ of $\mathrm{FeCl}_{2}(0.005 \mathrm{ml})$. The reaction was initiated by the addition of $5 \mathrm{mmol} / \mathrm{L}$ ferrozine $(0.2 \mathrm{ml})$ and the mixture was shaken vigoursly and left standing at room temperature for 10 to $15 \mathrm{~min}$. Absorbance of the solution was then measured spectrophotometrically at $562 \mathrm{~nm}$. The chelating activity of the extracts was evaluated using EDTA as the standard. The results were expressed in mg EDTA equivalent/g extract.

\section{Superoxide radical scavenging activity}

The scavenging activity towards the superoxide radical $\left(\mathrm{O}_{2}\right)$ was measured in terms of inhibition of generation of Oxygen (Sanchez-Moreno, 2002). The reaction mixture consisted of phosphate buffer $(50 \mathrm{mM}, \mathrm{pH} 7.6)$ riboflavin $(20 \mu \mathrm{g} / 0.2 \mathrm{ml})$. EDTA $(12 \mathrm{~mm})$, NBT $(0.1 \mathrm{mg} / 3 \mathrm{ml})$ and Sodium cyanide $(3 \mu \mathrm{g} / 0.2 \mathrm{ml})$. The aqueous extract was added in various concentrations of $50-200 \mu \mathrm{g} / \mathrm{ml}$ to make a total volume of $3 \mathrm{ml}$. The absorbance was read at $530 \mathrm{~nm}$ before and after illumination under UV lamb for 15 min against a control instead of the sample. The percentage of inhibition was calculated by using the same formula as given above.

\section{Ferric reducing antioxidant power assay}

Antioxidant capability of solvent extract of samples was estimated as described (Pulido et al., 2000). FRAP reagent $(900 \mu \mathrm{l})$, prepared freshly and incubated at $37^{\circ} \mathrm{C}$ was mixed with $90 \mu$ of distilled water and $30 \mu \mathrm{l}$ of test sample or methanol (for the reagent blank). The test samples and reagent blank were incubated at $37^{\circ} \mathrm{C}$ for $30 \mathrm{~min}$ in a water bath. The final dilution of the test sample in the reaction mixture was $1 / 34$. The FRAP reagent contained $2-5 \mathrm{ml}$ of $20 \mu \mathrm{mol} / 1$ 2,4, 6-tripyridyl -2-triazine (TPTZ) solution 
Table 1: Extraction yield and content of total polyphenols of root extract of Decalepis hamiltonii.

\begin{tabular}{cccc}
\hline Sample & \multicolumn{2}{c}{ Extraction yield (\%) } & \multicolumn{2}{c}{ Content } \\
\cline { 3 - 4 } & & Total phenols (mg GAE/g extract) & Total Flavonoids (mg CE/g extract) \\
\hline \multirow{2}{*}{ Aqueous extract } & $5.81^{\mathrm{a}}$ & $12.62 \pm 2.20^{\mathrm{b}}$ & $14.08 \pm 2.40^{\mathrm{c}}$ \\
\hline
\end{tabular}

Values (mean $\pm \mathrm{SD}, n=3$ ) in the same column followed by a different letter are significantly different $(p<0.05)$

${ }^{a}$ Extraction yield $(\%)=($ sample extract weight/sample weight $) \times 100 \%$. ${ }^{b} \mathrm{GAE}$, Gallic acid equivalents, ${ }^{\mathrm{c}} \mathrm{CE}$, Catechin equivalents.

in $40 \mu \mathrm{mol} / 1 \mathrm{HCl}$ plus $2.5 \mathrm{ml}$ of $20 \mu \mathrm{mol} / 1 \mathrm{Fecl} 3.6 \mathrm{H}_{2} \mathrm{O}$ and $25 \mathrm{ml}$ of $0.3 \mathrm{~mol} / \mathrm{l}$ acetate buffer $(\mathrm{pH} 3.6)$ as described by (Siddhuraju and Becker, 2003). At the end of incubation the absorbance readings were taken immediately at $593 \mathrm{~nm}$ using spectrophotometer. Methanolic solutions of known Fe II concentration ranging from 100 to $2000 \mu \mathrm{mol} / \mathrm{l}, \mathrm{FeSO}_{4} .7 \mathrm{H}_{2} \mathrm{O}$ were used for the preparation of the calibration curve. The FRAP value is expressed as mmol Fe (II) equivalent/mg extract.

\section{ABTS++ cation radical scavenging activity}

The total antioxidant activity of the samples was measured by ABTS radical cation decolourization assay according to the method (Re et al., 1996). In this improved version, ABTS the oxidant is generated by per sulfate oxidation of 2, 2-azinobis (3ethylbenzoline-6-Sulfonic acid) - (ABTS2-). ABTS radical cation $\left(\mathrm{ABTS}^{+}\right)$was produced by reacting ABTS solution $(7 \mathrm{mM})$ with $2.45 \mathrm{mM}$ ammonium per sulfate and the mixture were allowed to stand in dark at room temperature for 12 to $16 \mathrm{~h}$ before use. For this study different concentrations that ranges from 25 to $100 \mu \mathrm{g} / \mathrm{ml}$ of aqueous extract were added to $0.3 \mathrm{ml}$ of ABTS solution and the final volume was made up with aqueous to $1 \mathrm{ml}$. The absorbance was read at $734 \mathrm{~nm}$ and the percentage of inhibition was calculated.

\section{Statistical analysis}

The data were subjected to a one-way analysis of variance (ANOVA) and the significance of the difference between means was determined by
Duncan's multiple range test $(p<0.05)$ using statistical (Stat soft Inc., OK, USA). Values expressed are means of three replicate determinations \pm standard deviation.

\section{RESULTS AND DISCUSSION}

\section{Determination of Polyphenol}

The total phenolics and flavonoids content of the root aqueous extracts were found to be $12.62 \pm 2.20$ $\mathrm{g} / 100 \mathrm{~g}$ and $14.08 \pm 2.40 \mathrm{mg} / \mathrm{g}$ respectively (Table 1) compared with gallic acid, catechin equivalents. These phytochemical compounds are known to support bioactive activities in medicinal plants and thus responsible for the antioxidant activities of this plant extract used in this study.

\section{DPPH* radical scavenging activity}

The results on DPPH- radical scavenging activity of the aqueous tuber extracts along with the reference standards $\alpha$-tocopherol, rutin and butylated hydroxyl toluene (BHT) are shown in Figure 1. Concentration of the sample necessary to decrease initial concentration of $\mathrm{DPPH}^{*}$ by $50 \%$ (IC50) under experimental condition was calculated. Therefore lower value of $\mathrm{IC}_{50}$ indicates higher antioxidant activity of $135.59 \mu \mathrm{g} / \mathrm{ml}$. In this study indicates that the plant was potently active and these plant extract contain polyphenol compounds that are capable of donating hydrogen to a free radical in order to remove odd electron which is responsible for radical's reactivity. Free radicals are chemical entities that can exist individually with one or more unpaired elec-

Table 2: Metal chelating activity, FRAP and ABTS.+ assay of root extract of Decalepis hamiltonii.

\begin{tabular}{|c|c|c|c|}
\hline Sample & $\begin{array}{c}\text { Metal chelating } \\
\text { mg EDTA/g sample }\end{array}$ & $\begin{array}{c}\text { FRAP } \\
(\mu \mathrm{mol} \mathrm{Fe}(\mathrm{II}) / \mathrm{mg} \text { extract })\end{array}$ & $\begin{array}{c}\text { TAA } \\
(\mu \mathrm{mol} / \mathrm{g} \text { extract })\end{array}$ \\
\hline Aqueous extract & $108 \pm 1.0^{\mathrm{a}}$ & $746.89 \pm 4.90^{\mathrm{b}}$ & $2620.8 \pm 1566.8^{c}$ \\
\hline
\end{tabular}




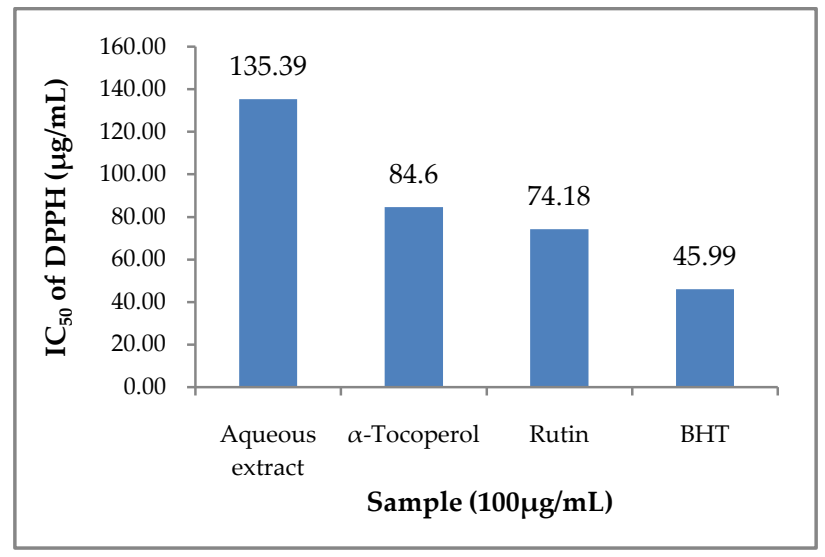

Figure 1: DPPH Radical scavenging activity of aqueous root extract of Decalepis hamiltonii

trons. The generation of free radicals can bring about thousands of reactions and thus cause extensive tissue damage. Lipids, proteins and DNA are all susceptible to attack by free radicals (Cotran et al., 1999).

\section{Metal chelating activity}

Presence of transition metal ions in biological system could catalyse the Haber-Weiss and Fentontype reactions, resulting in generation of hydroxyl radicals $\left(\mathrm{OH}^{*}\right)$. However, these transition metal ions could form chelate with the antioxidants, which result in the suppression of $\mathrm{OH}^{*}$ generation, and inhibit the peroxidation process of biological molecules. The chelating effect of $D$. hamiltonii root extract on ferrous ion is shown in Table 2. It was observed that the maximum inhibition $(108.0 \mathrm{mg}$ EDTA/g extract) was observed in the $50 \mu \mathrm{g} / \mathrm{ml}$ concentration and the inhibitory effect started to decrease after this concentration. The chelate might be due to high concentration of phenolic compounds that can chelate metal ions. Metal chelating capacity was significant as they reduced the concentration of the catalyzing transition metal in lipid peroxidation (Duh et al., 1999).

\section{Superoxide radical scavenging activity}

Superoxide anion plays an important role in plant tissues and is involved in the formation of other celldamaging free radicals (Duan et al., 2007). The relative scavenging effects of D. hamiltonii and BHT towards superoxide anion radicals are shown in Figure 2. Plant sample extract exhibited excellent superoxide anion scavenging activity as compared

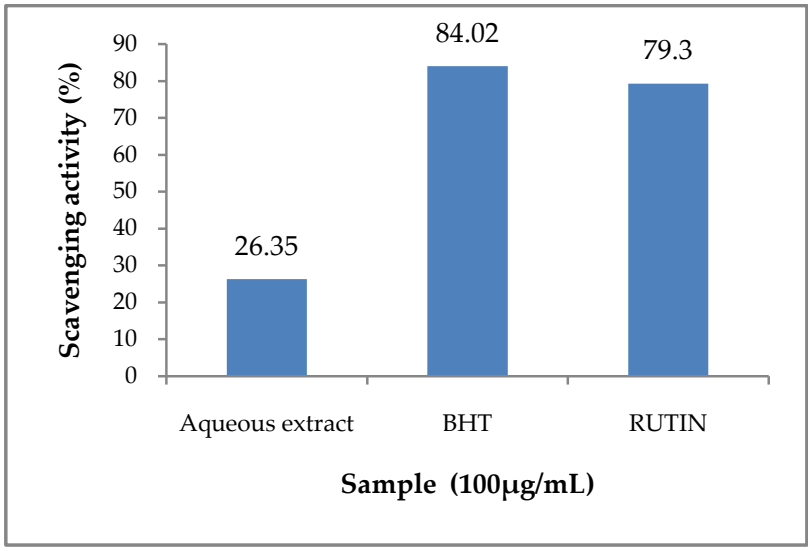

Figure 2: Superoxide radical scavenging activity of aqueous root extract of Decalepis hamiltonii

with BHT and Rutin. The effect values were found to be $(26.35 \%)$ followed by BHT $(84.2 \%)$ and Rutin (79.3\%) respectively. It is known that the hydroxyl group of the phenolics contributes to superoxide anion scavenging activity by their electron donation (Bravo, 1998).

\section{Ferric reducing antioxidant power assay}

FRAP assay directly measured antioxidant or reductants in a sample that react with ferric tripyridyltriazine $\left(\mathrm{Fe}^{3+} \mathrm{TPTZ}\right)$ complex and produce coloured ferrous tripyridyltriazine ( $\left.\mathrm{Fe}^{2+} \mathrm{TPTZ}\right)$. The antioxidant ability of sample extract of $D$. hamiltonii varied significantly $(\mathrm{p}<0.05)$ (Table 2$)$ and the root extract showed higher FRAP antioxidant activity (746.89 mmol/Fe II/mg). The phenolic compounds exhibited reduction properties by acting as reducing agents, hydrogen donators and singlet oxygen quenchers (Rice-Evans et al., 1997).

\section{ABTS-+ cation radical scavenging activity}

ABTS++ cation radical scavenging activity decolorization assay applicable to both lipophilic and hydrophilic antioxidants including flavonoids, hydroxycinnamates, carotenoids, and plasma antioxidants. The pre-formed radical monocation of 2,2'-azinobis-(3-ethylbenzothiazoline-6-sulfonic acid) (ABTS $\bullet$ ) is generated by oxidation of ABTS with potassium persulfate and is reduced in the presence of such hydrogen-donating antioxidants. The activity of tested sample extract is expressed as a micromolar equivalent of Trolox solution, having an antioxidant ability equivalent to $1 \mathrm{~g}$ of dry matter of the extract under the experimental investigation. 
The effect of aqueous extract of $D$. hamiltonii on ABTS+ cation radical scavenging activity is shown in Table 2 and the root extract exhibited higher total antioxidant activity of $2620.8 \mu \mathrm{mol} / \mathrm{g}$. The scavenging activity of ABTS+ radical by the plant extract was found to be appreciable; this implies that the plant extract may be useful for treating radical related pathological damage especially at higher concentration (Wang et al., 1998). Polyphenols are the major plant compounds with antioxidant activity, although they are not the only ones. The antioxidant activity of phenolic compounds is reported to be mainly due to their redox properties (Galato et al., 2001; Zheng and Wang, 2001), which can play an important role in adsorbing and neutralizing free radicals, quenching singlet and triplet oxygen, or decomposing peroxides.

\section{CONCLUSION}

In conclusion, the present study shows that polyphenols content in the aqueous root extracts of Decalepis hamiltonii is high and these extracts exhibit strong antioxidant activities compared to that of the standard compounds such as $\alpha$-Tocoperol, Rutin and Butylated hydroxytoluene (BHT). Hence, this investigation suggested that the plant naturally having rich source of antioxidants could be used in the prevention of free radical diseases and general health tonic.

\section{ACKNOWLEDGEMENT}

The authors are thankful to University Grants Commission, New Delhi, India for providing financial [(Ref. No. F. 14-2(ST)/2010 SA (III)] support during this research work.

\section{REFERENCES}

Anon, M. (1952). The wealth of India. First supplemented series (raw material). NISC and CSIR, New Delhi, India; Vol. 1.

Blios, M.S. (1958). Antioxidant determination by the use of a stable free radical. Nature, 26: 1199-1200. DOI

Bravo, I. (1998). Polyphenols: Chemistry, dietary sources, metabolism, and nutritional significance. Nutrition Review, 56: 317-333. DOI
Cotran, R.S., Kumar, V., Collins, T. (1999). In Robbin's pathological basis of disease, 6th ed (Thomson press (I) Ltd), Noida, India.

Dinis, T.C.P., Maderia, V.M.C., Almedia, L.M. (1994). Action of phenolic derivatives (acetoaminophen, Salycilate and 5 amino salycilate) as inhibitors of membrane lipid peroxidation and as peroxyl radical scavenges. Arch. Biochem. Biophys.; 315: 161-169. DOI PMid:7979394

Duan, X., Wu, G., Jiang, Y. (2007). Evaluation of antioxidant properties of phenolics from litchi fruit in relation to Pericarp browning prevention. Molecules, 12: 759-771. DOI PMid:17851428

Duh, P.D., Tu, Y.Y., Yen, G.C. (1999). Antioxidant activity of water extract of Harng Jyur (Chrysanthemum morifolium Ramat). Lebensmittel-Wissenschaft Technolog., 32: 269277. DOI

Ebadi, M. (2002). Pharmacodynamic basis of Herbal Medicines (CRC Press, Boca Raton), pp: 86.

Fiorucci, S. (2006) Theses: Active biologiques de compose de la families des flavonoids: Approches par des methods de chimie quantique et de dynamique molcularie. Soutenue a Universite de Nice-Sophia Antipolis, pp 212.

Galato, D., Ckless, K., Susin, M.F., Giacomelli, C., Ribeiro-doValle, R.M, Spinelli, A. (2001). Antioxidant capacity of phenolic and related compounds: correlation among electrochemical, visible spectroscopy methods and structureantioxidant activity. Redox Report, 6: 243-250. DOI PMid:11642715

Giridhar, P., Rajasekaran, T., Nagarajan, S., Ravishankar, G.A (2004). Production of 2-hydroxy-4-methoxy benzaldehyde in roots of tissue culture raised and acclimatized plants of Decalepis hamiltonii Wight \& Arn ., an endangered shrub endemic to Southern India and evaluation of its performance vis-à-vis plants from natural habitat, Indian J. Exp Biol., 42: 106. PMid:15274490

Gupta, M., Mazumder, U.K., Gomathi, P. and Kumar, R.S. (2004). Antioxidant and free radical scavenging activities of Ervatamia coronaria Stapf. leaves, Iranian. J. Pharm. Res., 2: 119.

Kumaran, A. and Karunakaran, J.R. (2007). In-vitro antioxidant activities of methanol extracts of five Phyllanthus species from India, LWT Food Sci. Technol., 40(2): 344. DOI

Pulido, R., Bravo, L., Sauro-Calixo, F. (2000). Antioxidant activity of dietary polyphenols as determined by a modified ferric reducing/antioxidant power assay, J. Agri. Food chem., 48: 3396-3402. DOI PMid:10956123

Re, R., Pellegrini, N., Proteggente, A., Pannala, A., Yang, M., Rice-Evans, C. (1999). Antioxidant activity applying an improved ABTS radical cation decolorization assay. Free. Radic. Bio-Med, 26: 1231-1237. 
Rice-Evans, C., Miller, N. and Pagana, G. (1997). Antioxidant properties of phenolic compounds. Trends Plant Sci., 2 : 152-159. DOI

Sanchez-Moreno, C. (2002). Review: Methods used to evaluate the free radicals scavenging activity in foods and biological systems. Food science Tech Int., 8(3): 121-137.

Siddhuraju, P. and Becker, K. (2003). Studies on antioxidant activities of Mucuna seed (Mucuna prurienns var. utilis) extracts and certain non-protein amino/imino acids through in vitro models. J. Sci. Food Agri., 83: 1517-1524. DOI

Soares, J.R., Dinis, T.C.P., Cunba, A.P., Almedia, L.M. (1997). Antioxidant activities of some extract of Thumus zygis. Free. Radic. Res, 13: 8-17.
Vedavathy, S. (2004). Decalepis hamiltonii Wight \& Arn. - An endangered source of indigenous health drink. Natural Product Radiance, 3 (1): 22-23.

Wang, M., Li, J., Rangarajan, M., Shao, Y., La Voie, E.J., Huang. T., Ho, C. (1998). Antioxidative phenolic compounds from sage (Salvia officinalis). J Agric Food Chem., 46: 4869-4873. DOI

Zheng, W., Wang, S.Y. (2001). Antioxidant activity and phenolic compounds in selected herbs. J of Agri. and Food Chem., 49:5165-5170. DOI PMid:11714298

Zhishen, J., Mengcheng, T., \& Jianming, W. (1999). The determination of flavonoid contents in mulberry and their scavenging effects on superoxide radicals. Food Chemistry, 64: 555-559. DOI 